\title{
The Characteristic of Folding Cyclists on the Selection of Transportation Modes in the City of Palembang
}

\author{
Efrilia Rahmadona ${ }^{1, *}$ Sudarmadji $^{1}$ Norca Praditya ${ }^{1}$ M. Ade Surya Pratama ${ }^{1}$ \\ ${ }^{1}$ Politeknik Negeri Sriwijaya \\ *Corresponding author. Email: efriliarahmadona@poslri.ac.id
}

\begin{abstract}
Sustainable Transportation is one of the embodiment of sustainable development, sustainable development puts forward the concept of eco-friendly urban, where the concept aims to balance the increasingly rapid development activities with an eco- friendly transportation system that is integrated with other modes of transportation, particularly the public transportation. Through this research, it is expected that it will become a reference for planning the development of bicycle routes and lanes in the city of Palembang. The research method used was a quantitative descriptive approach, data collection techniques conducted through a questionnaire survey, the total population was 966 cyclists, the sample taken for respondents with the Slovin formula was 478 respondents. The sampling technique used was simple random sampling, the results of data processing will be illustrated in tables and diagrams and calculations for the study of bicycle route lane using a matrix of origin and destination. Based on the questionnaire data obtained, from the survey results of 478 respondents, the percentage of cyclist was predominantly male and it was $91 \%$, based on the analysis of activity patterns of folding cyclists, it indicated that the use of bicycle was $77 \%$ and it intended to the purpose of sports trips, $8 \%$ was for the purpose of recreation, $6 \%$ was for the purpose of daily activities, $5 \%$ was for the purpose of social travel, and the last $4 \%$ was for work purposes. $20 \%$ of folding cyclists were aimed to the short trips $\leq 10 \mathrm{~km}$, while the use of bicycles for medium distances, which was around $10 \mathrm{~km}$ to $40 \mathrm{~km}$, with the largest percentages was 38\% and 32\%. 68\% of folding cyclist stated that the bicycle mode was the most economical mode of transportation. Dealing with the analysis for the opportunity to develop special bicycle routes and lanes, bicycle users were enthusiastic to obtain supporting facilities in the form of special bicycle lanes, $97 \%$ of cyclists agreed that a special bicycle lane must be provided. The selection of roads for bicycle routes was based on the calculation of the origin and destination matrix for the cyclists, the districts of the most potential cyclists were selected as starting and ending points for the bicycle route. Thus, 2 alternatives were selected for the special bicycle route.
\end{abstract}

Keywords: sustainable transportation, characteristics, bicycle route, bicycle lane

\section{INTRODUCTION}

\subsection{Background}

Sustainable Transportation is one of the forms of sustainable development, sustainable development puts forward the concept of an eco- friendly urban, where the concept aims to balance the increasingly rapid development activities with an eco- friendly transportation system that is integrated with other modes of transportation, particularly the public transportation. 
During the last decade, with increasing the amount of traffic on the road, the private vehicles has dominated so then it leads to the transportation problems, namely traffic congestion, the problem of air pollution that caused by vehicle fumes and it has become a crucial issue in the world of transportation in Indonesia. Along with the development of technology and transportation, the more it is easier to access modes of transportation, it has an effect on the trend of choosing the transportation mode has been used nowadays. So far, the Indonesian government, especially in big cities like Palembang, has attempted to improve public transportation facilities and infrastructure to make people alter from private transportation to mass transportation, by providing mass transportation such as Bus Rapid Transit (BRT) and LRT. Besides, a more eco- friendly mode of transportation, namely bicycles, currently in Palembang city, there are several bicycle communities such as Bike to work. However, the increase in bicycle users in Palembang has not been adjusted by supporting facilities for cyclist, such as the provision of special bicycle lanes and bicycle parking. Several studies on cyclists that have been carried out include: (i) The Characteristic of Bicycles in Medono Village, Pekalongan Barat District by Ruruh Tri, et al (2014); (ii) Development of Pedestrian and Cyclist Lanes in an Effort to Support the UGM Campus Based on Educopolis by Marianna S. Manulang (2014); (iii) Need Analysis of Pedestrians and Cyclists in the Selong Area of East Lombok Regency by Wilda I, et al (2017) (iv) Development of Bicycle Routes in accordance with Standards and Needs that Support Bike To Work in the city of Bandung by Mirakania N, et al (2016). Thus, it would be very useful to conduct research on the description of folding cyclists in the city of Palembang and opportunities for developing bicycle routes and lanes in the city of Palembang. Based on the research that has been done on cyclists, it will be studied further regarding the characteristics of bicycle users, the choice of public transportation modes of transportation by bicycle users in Palembang City. Therefore, this research is expected to become a reference for planning the development of bicycle routes and lanes in the city of Palembang.

\subsection{Literature review}

\subsubsection{State of the Art}

Several research that have been conducted on cyclists, it includes:

1. Ruruh Tri A, et al (2014), entitled: Characteristics of Bicycle Use in Medono Village, Pekalongan Barat District.

2. Marinna S. Manulang (2014), entitled: The Development of Pedestrian and Cyclist Lanes in an Effort to Support the Ugm Campus Based on Educopolis

3. Pipit Rusmandani (2015), the title is: Planning for the Implementation of Bike Lanes in Tegal City.

4. Mirakania, et al (2016), with the title is Development of Bicycle Routes in accordance with Standards and Needs that Support Bike To Work in the city of Bandung.

\subsubsection{Transportation}

According to Bowersox (1981), transportation is the movement of goods or passengers from one place to another, where the product is moved to the required destination. In general, transportation is an activity to move something (goods and / or goods) from one place to another, either with or without means. Meanwhile, according to Warpani (1990) states that the determinants of movement that can be applied in Indonesia are: family income, number of vehicle ownership, distance from city activity centers, mode of travel, vehicle use and time.

\subsubsection{Sustainable Transportation}

The definition of sustainable transportation is transportation that serves its primary purpose as the urban drivers of economic growth and social development. The definition issued by The World Bank (1996) emphasizes transportation activities in the concept of sustainable transportation in the regional economic and social development aspects. This concept of transportation system is applied to 
facilitate economic activity in the region. Economic activity can advance if it is supported by good transportation. One of the forms of sustainable transportation is the use of non-motorized transportation, which is considered environmentally friendly. Eco-friendly transportation is a concept or movement that encourages the use of motorized vehicles.

\subsubsection{Data Collection Techniques}

Primary data collection techniques can be undertaken in the following steps. Sugiyono (2013: 194) suggests that there are three data collection techniques, namely interviews, questionnaires and observation. Population is the total of all objects or individuals that have certain, clear and complete characteristics to be examined. (Iqbal, 2002). The sample is part of the number and characteristics of the population (Sugiyono, 2009).

\subsubsection{Sample Size}

To determine the number of reflective samples is used through a sampling technique based on the Slovin formula (Bambang Prasetyo, 2005: 136), which is as follows:

$\mathrm{n}=\frac{N}{1+N \cdot e^{2}}$

\section{Description:}

$\mathrm{N}=$ Population size

$\mathrm{n}=$ Sample Size

$\mathrm{e}=$ Percentage of error rate $(1 \%, 5 \%, 10 \%)$

One of the ways to process movement data is to use a movement matrix (Origin Destination Matrix). This matrix describes movement patterns that can be analyzed to indicate the problems and then design solutions.
Table 1. Matrix origin and destination

\begin{tabular}{|c|c|c|c|c|c|c|c|c|}
\hline Zone & 1 & 2 & 3 & 4 & & oi & Oi & Ei \\
\hline 1 & & & & & & & & \\
\hline 2 & & & & & & & & \\
\hline 3 & & & & & & & & \\
\hline 4 & & & & & & & & \\
\hline $\mathrm{dj}$ & & & & & & & & \\
\hline $\mathrm{Dj}$ & & & & & & & & \\
\hline $\mathrm{Ej}$ & & & & & & & & \\
\hline
\end{tabular}

\section{RESEARCH METHOD}

\section{Research Setting}

The method used in the study of "Characteristics of Folding Cyclists on the Selection of Public Transportation in Palembang City" was a quantitative descriptive approach method by $\mathrm{n}=$ the city of Palembang.

This research was conducted for 6 months starting from May to October 2020 along the road routes traversed by the folding bicycle jamboree participants in Palembang, along the road routes was started from Jl. Governor. A. Bastari, Jl. Jend. A. Yani, Jl. Perintis Kemerdekaan, Jl. Veteran, Jl. Jend. Sudirman, J1 Demang Lebar Daun, and J1. Independent.

The research method used in this research was quantitative descriptive approach method. This research was conducted on the community of folding bicycle along the route road traversed by the folding bicycle jamboree in Palembang. This route started from Jl. Governor. A. Bastari, Jl. Jend. A. Yani, Jl. Perintis Kemerdekaan, Jl. Veteran, Jl. Jend. Sudirman, J1 Demang Lebar Daun, J1. Merdeka. Then, data collection techniques used was a survey by distributing questionnaires. In this research, the total population was 966 cyclists, the samples were taken for respondents with the Slovin formula as many as 478 respondents. The sampling technique used was Simple Random Sampling. Thus, this sampling of sample members from the population was done randomly without paying attention to the strata in the population. The survey results that have been obtained, definitely, there were still some data 
in the form of qualitative data, to convert it into quantitative data, the data will be processed using a frequency distribution table, which will be in the form of research results on the characteristics of folding cyclists in Palembang, including socioeconomic characteristics, namely age, type gender, education, income, type of bicycle, distance traveled, time traveled, perception of cyclists willing to use bicycle lanes if available, perceptions of cyclists who have willingness to use bicycle lanes if it is available, perceptions of cyclists on the use of available public transportation. Furthermore, it examines the potential development for special bicycle routes and lanes in Palembang City in which it used matrix analysis of origin and destination, from this data, it will be known how much interest of cyclists on the availability of special bicycle lane facilities in Palembang City, so that they can determine potential areas for starting and ending points of the bike lane route.

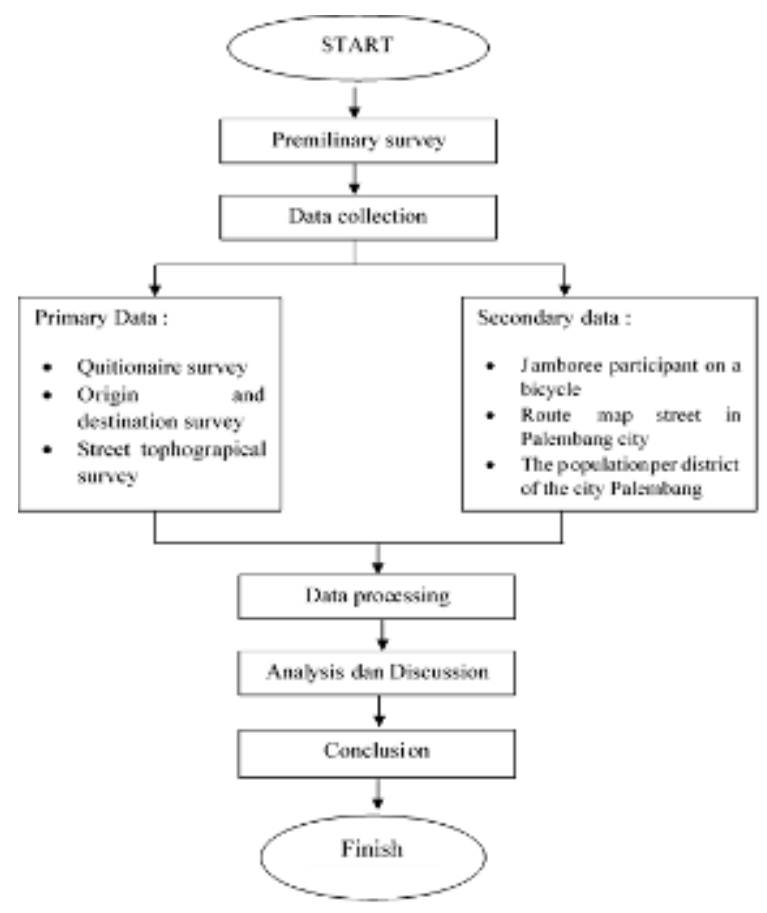

Figure 1. The Flow Chart of Research

\section{FINDING AND DISCUSSION}

\subsection{Analysis of the characteristics on folding cyclists.}

Based on the results of the distribution of questionnaires from the survey results on 478 respondents, the percentage of male cyclists is higher (91\%) than the female population is merely (9\%). In Palembang city, the use of bicycles does not depend on how old the users are. Percentage of bicycle use by the population at productive age, namely the age $30-40$ years is higher, which is $46 \%$ when compared to the user in the age of 50 years and over, those are only 5\%. In addition, based on the data obtained, it shows that the use of bicycles is not only carried out by people with low levels of education but also dominated by people with high levels of education such as bachelor degree is $41 \%$ and master degree is $24 \%$.

\subsection{Analysis of activity patterns of folding cyclists.}

Based on the results of the questionnaire data processing, it indicates that $77 \%$ of bicycle use is used for sports travel purposes, $8 \%$ is used for recreation, $6 \%$ is for the purpose of daily activities, $5 \%$ is for social travel purposes, and the last $4 \%$ is for work purposes.

Most people who use bicycle, especially for sports purposes, they are residents who generally worked as government employees and private employees. Based on the results of data processing, it is obtained from the distribution of questionnaires, $38 \%$ of the bicycle use is carried out to take long distances, which is about $10-20 \mathrm{~km}$ with a travel time about 30-60 minutes.

\subsection{Travel Mileage}

Based on the survey results, folding bicycle users for short trips $\leq 10 \mathrm{~km}$ are dominated by male government employees in the age range between 30 40 years with a percentage of $20 \%$. Meanwhile, the use of bicycles for medium distances is around $10 \mathrm{~km}$ to $40 \mathrm{~km}$ with the largest percentages of $38 \%$ and 


\begin{tabular}{|c|c|c|}
\hline No & Cost & Percentage \\
\hline 1 & 0 & $17 \%$ \\
\hline 2 & < IDR. 10.000 & $11 \%$ \\
\hline 3 & IDR. 10.000 - IDR. 25.000 & $30 \%$ \\
\hline 4 & IDR. 25.000 - IDR. 50.000 & $20 \%$ \\
\hline 5 & > IDR. 50.000 & $22 \%$ \\
\hline
\end{tabular}

$32 \%$. For the relatively long distances between $30 \mathrm{~km}$ and $>60 \mathrm{~km}$ are carried out by residents who work as government employees with the majority of graduate is $\mathrm{S} 1$ and it is dominated by men that aged between 30-40 years.

Table 2. Mileage

Source : Data Analysis, 2020

And also the relatively short distance that use bicycle, it does not take a long time and it merely takes 30-60 minutes and this is known to be $30 \%$. While, the shortest travel time is $<10$ minutes, this travel time is rarely taken because it is only $2 \%$ of cyclists who take this time.

\subsection{Traveling Time}

Based on the survey results, the majority of the travel time taken by folding cyclists in Palembang is 30-60 minutes. Considering that the majority of the purpose of cycling is merely for exercise.

\begin{tabular}{|c|c|c|}
\hline No & Time & Percentage \\
\hline 1 & $<10$ Minute & $2 \%$ \\
\hline 2 & $10-30$ Minute & $16 \%$ \\
\hline 3 & $30-60$ Minute & $30 \%$ \\
\hline 4 & $60-90$ Minute & $26 \%$ \\
\hline 5 & $>90$ Minute & $27 \%$ \\
\hline
\end{tabular}

Table 3. Travel Time

Source : Data Analysis, 2020

\subsection{The Cost of Travel}

The cost of traveling by bicycle is very economical, it is discovered that $17 \%$ cyclists are government employees in the age of 30-40 years and they argue that they do not spend Rp. 0, - even for the cost of transportation. Most of these users are male. Meanwhile, the cost of travel is between IDR 10,000 to IDR 25,000 , it is known that $30 \%$ of users are between 20-30 years and 30-40 years old, where the majority of users are male residents dominated by employees and government employees.

Table 4. Travel Cost

Source: Data analysis, 2020

\subsection{The Safety - Convenience Based selection of Mode of Transportation}

\begin{tabular}{|c|c|c|}
\hline No & Distance & Percentage \\
\hline 1 & $<10 \mathrm{Km}$ & $20 \%$ \\
\hline 2 & $10-20 \mathrm{Km}$ & $38 \%$ \\
\hline 3 & $30-40 \mathrm{Km}$ & $32 \%$ \\
\hline 4 & $50-60 \mathrm{Km}$ & $5 \%$ \\
\hline 5 & $>60 \mathrm{Km}$ & $5 \%$ \\
\hline
\end{tabular}

It points out that $46 \%$ of respondents argue that bicycles are the safest and most convenience mode of transportation to be used when traveling. Whereas, $36 \%$ of respondents choose to use a car for a safety and convenience in travelling. While the rest chooses the motorized transportation modes, public transportation and others.

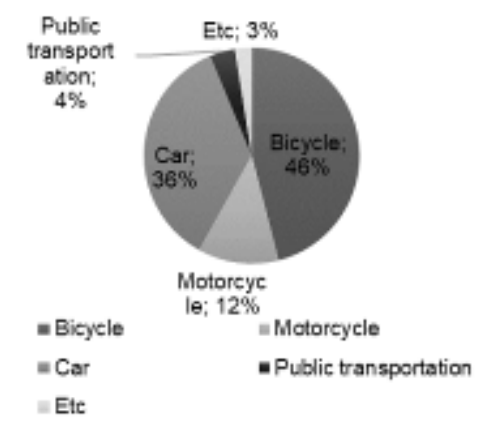

Figure 2. Selection of Transportation Mode Source : Data Analysis, 2020

For the level of safety and convenience, based on the selection of transportation mode, the lowest percentage is public transportation, which is only 4\%. This is due to the existing public transport services do not cover all areas in the city of Palembang. 


\subsection{Analysis of the Characteristics of Cyclist in terms of Economy, Convenience and Activity Patterns of Cyclist}

Income is one of the factors that effect on the use and choice of transportation modes in society life. The limitation of income obtained by some people, it requires them to choose and use the mode that adjusts with their economic needs and abilities. However, the convenience and safety also affect the cyclist in choosing the mode of transportation. Based on questionnaire data processing, it points out that $68 \%$ of folding cyclists in city of Palembang state that the bicycle mode is the most economical mode of transportation.

\subsection{Study of Route Development Opportunities and Bike Lane}

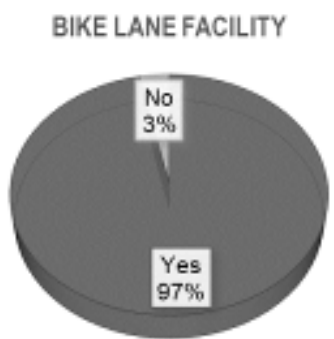

Figure 3. Facility of Bike Route

Source : Data Analysis, 2020

Based on the data that has been obtained and analyzed for opportunities to develop special bicycle routes and lanes, cyclists are enthusiastic to obtain supporting facilities in the form of special bicycle lanes, through the questionnaire, it can be seen that $97 \%$ of cyclists agree that the government provides a special bicycle lane.

The development of a bicycle route needs to determine the origin and destination as the starting and the ending point by connecting the two points, the questionnaire data was then processed into the origin and destination data to assess the route. This can be seen from the calculation of the origin and destination matrix of the cyclists. The matrix was divided by district from origin and destination of cyclists.

Table 5. Matrix origin and destination

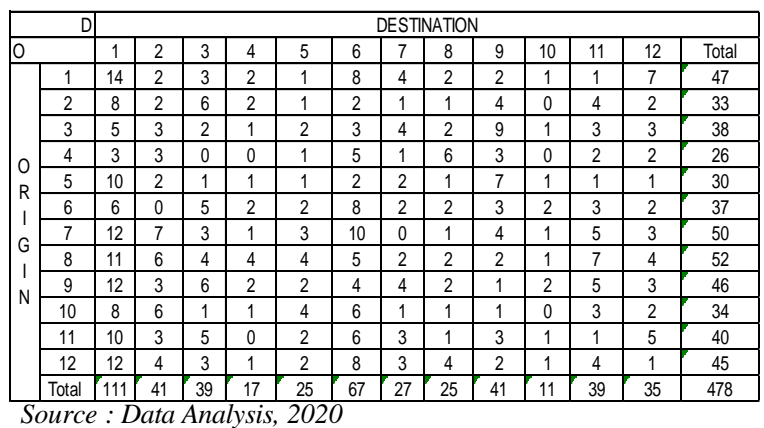

Description of Origin :1 = Ilir Timur 1, 2 = Ilir Timur 2, $3=$ Plaju, $4=$ Kertapati, $5=$ Kemuning, $6=$ Ilir Barat 1 , $7=$ Sukarami, $8=$ Alang-alang lebar, $9=$ Bukit Kecil, 10 = Gandus, $11=$ jakabaring, $12=$ Sako

Description of Destination :1 = Ilir Timur 1, $2=$ Ilir Timur 2, 3 = Plaju, $4=$ Kertapati, $5=$ Kemuning, $6=$ Ilir Barat $1,7=$ Sukarami, $8=$ Alang-alang lebar, $9=$ Bukit Kecil, $10=$ Gandus, $11=$ jakabaring, $12=$ Sako

Based on the analysis of the data obtained, the potential districts to be used as starting points for the route are Jakabaring, Ilir Barat 1 and Sukarami sub-districts, this is the basis for determining the location that will be used as the starting point (origin). Further, identify the road that is passed by the cyclists in accordance with the district. The next step from the concentration of the distribution of the district area is re-analyzed based on the matrix of origin of destination with the most potential destination numbers, there are three districts with the most potential to be used as destinations, namely, Ilir Timur 1, Ilir Barat 1 and Bukit Kecil sub-districts based on the movement of the cyclists. After the initial and final routes have been determined, the next is a temporary mapping of bicycle lanes in the city of Palembang, by conducting the direct observations on several roads in city of Palembang. The selection of road for the bicycle route is based on the road that passes through the district of origin and destination of the cyclist. Thus, 2 alternatives are selected for the special bicycle route, namely: 
1. Jakabaring sport city - St. Gubernur H.

Bastari - St. H.M Ryacudu - Jembatan Ampera - St. Merdeka - St. Rumah bari - Benteng Kuto Besak (PP)

2. Kambang Iwak - St. Tasik - St. Ki Renggo Wirosantiko - St. Kapt. A.Rivai - St. POM IX - St. Sumpah Pemuda - St. Angkatan 45 - St. Kapt. A.Rivai - St. Ahmad Dahlan -,St. Tasik ( Kambang Iwak)

\section{CONCLUSION}

Based on the analysis of the characteristics of folding bicycle users that:

1. Based on the results of the distribution of questionnaires from the survey results on 478 respondents, it indicated that the cyclists were dominated by male and the total was $91 \%$. The percentage of cyclists at the productive age of $30-40$ years old were $46 \%$ and it was higher than the cyclists at the old age, namely 50 years and over, were only $5 \%$. The use of bicycles was not only carried out by people with low levels of education but also dominated by people with higher education levels such as undergraduate graduate was $41 \%$ and master degree was around $24 \%$.

2. According to the analysis of the activity patterns of folding bicycle users, the results of the questionnaire data processing, it pointed out that $77 \%$ of bicycle use was used for the purpose of sports travel, $8 \%$ was for recreational purposes, $6 \%$ was for the purpose of daily activities, 5\% was for the purpose of social travel, and $4 \%$ was for work purposes.

3. Based on the survey results, folding cyclists for short trips $\leq 10 \mathrm{~km}$ were dominated by male government employees in the age range between $30-40$ years with a percentage of $20 \%$. Meanwhile, the use of bicycles for medium distances was around $10 \mathrm{~km}$ to $40 \mathrm{~km}$ with the largest percentage was $38 \%$ and $32 \%$.

4. Based on questionnaire data processing, it showed that $68 \%$ of folding cyclists in the city of Palembang argued that the bicycle mode was the most economical mode of transportation.

5. Based on the analysis for the opportunities on development of special bicycle routes and lanes, enthusiastic the cyclists were enthusiastic to obtain supporting facilities in the form of special bicycle lanes, $97 \%$ of cyclists agreed that a special bicycle lane need to be provided.

6. The selection of roads for bicycle routes was based on the calculation of the origin and destination matrix of bicycle users, the districts of the most potential cyclists were selected to be used as starting and ending points for the bicycle route. Thus, 2 alternatives were selected for the special bicycle route, namely:

a. Jakabaring sport city - St. Gubernur H.

Bastari - St. H.M Ryacudu - Jembatan Ampera St. Merdeka - St. Rumah bari - Benteng Kuto Besak (PP)

b. Kambang Iwak - St. Tasik - St. Ki Renggo Wirosantiko - St. Kapt. A.Rivai - St. POM IX St. Sumpah Pemuda - St. Angkatan 45 - St. Kapt. A.Rivai - St. Ahmad Dahlan -, St. Tasik ( Kambang Iwak)

\section{AUTHORS' CONTRIBUTIONS}

Sudarmadji, Efrilia Rahmadona, Norca Praditya, and M. Ade surya Pratama contributed to the design and implementation of the research, to the analysis of the results and to the writing of the manuscript

\section{ACKNOWLEDGMENTS}

Thank you to Sriwijaya State Polytechnic

\section{REFERENCES}

[1] TZ. 2009. Pedestrian and Bicycle Planning: A Guide to Best Practices. Utrecht.

[2] Putri, Ruruh Tri A, dkk 2014. Karakteristik Penggunaan Sepeda di Kelurahan Medono Kecamatan Pekalongan Barat. Jurnal Ruang Vol. 2 No 3.

[3] Marinna S. Manulang. 2014. Pengembangan Jalur Pejalan Kaki Dan Pengendara Sepeda 
Dalam Upaya Mendukung Kampus Ugm Berbasis Educopolis

[4] Pipit Rusmandani. 2015. Perencanaan Implementasi Lajur Sepeda di Kota Tegal

[5] Nasution, Mirakania., Dirgahayani, Puspita. 2016. Pengembangan Rute Sepeda Sesuai Standar Dan Kebutuhan Yang Mendukung Bike To Work Di Kota Bandung. Jurnal Sekolah Arsitektur, Perencanaan dan Pengembangan Kebijakan ITB

[6] roaddus, Andrea, Todd Litman, dan Gopinath Menon. 2009.2 Transportation Demand Management. Germany: GTZ.
[7] Iqbal, H.M. 2002. Pokok-Pokok Materi Statistik 2. Jakarta: PT. Bumi Aksara. Khristy,C.J., dan Lall, B.K. 2002. DasarDasar Rekayasa Transportasi Jilid 2. Jakarta: Erlangga

[8] Prasetyo, Bambang. dan Jannah, L.M. 2005. Metode Penelitian Kuantitatif. Jakarta: Rajagrafindo Persada.

[9] Amin, Ofyar Z. 1997. Perencanaan dan Permodelan Transportasi. Bandung : Penerbit ITB. 